\title{
Lézerrel felületkezelt dentális implantátumok túlélési és sikerességi rátájának vizsgálata
}

\author{
DR. JOÓB-FANCSALY ÁRPÁD*, DR. DIVINYI TAMÁS*, KARACS ALBERT**, \\ KONCZ SZILVIA*, PETŐ GÁBOR ${ }^{\star *}$, DR. SULYOK LILI*
}

\begin{abstract}
A dolgozat célja retrospektív vizsgálattal összehasonlítani a több mint 8 éve beültetett, nagyteljesítményű Nd/üveg lézerrel felületkezelt implantátumok túlélési és sikerességi rátáját klinikai és radiológiai módszerekkel.

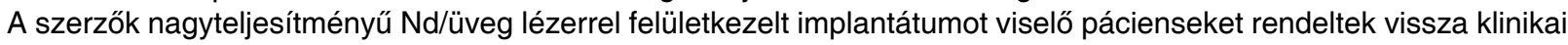
és radiológiai kontrollra. Az implantációk 1997 és 2006 között történtek. Az implantátumok vizsgálata és elemzése szigorú sikerességi kritériumok alapján történt. A klinikai és radiológiai vizsgálatok hasonló eredményeket mutattak a lézeresen felületkezelt implantátumok sikerességi és túlélési rátájával kapcsolatban, mint az irodalomban gyakran szereplő homokfúvott és kémiai maratáson átesett implantátumok esetében.

A kapott eredmények alapján megállapítható, hogy a lézeresen felületkezelt implantátumok sajátos felületi morfológiája és nagyfokú tisztasága kiváló csontintegrációhoz vezet és hosszú távon is megbízható klinikai felhasználhatóságot biztosít.
\end{abstract}

Kulcsszavak: fogászati implantátum, sikerességi ráta, felületi morfológia, túlélési ráta, lézeresen kezelt felszín, klinikai és radiológiai vizsgálat

\section{Bevezetés}

A fogászati implantológia alaptudományának reflektorfényébe kerültek a felületmorfológiai kérdések. Albrektsson és Branemark több mint harminc éve megfogalmazta a csontintegráció feltételeit, amelyek közül az implantátum felülete kiemelten hangsúlyos szerepet kap azóta is [1]. Az elmúlt három évtizedben a felület szerepének kérdése sokat finomult, már nemcsak a felület tisztaságára és morfológiájára fókuszálnak a kutatók, hanem a felület pontos kémiai összetételére, szennyezettségének pontos feltérképezésére, a felület hidrofilitására, illetve annak hiányára $[4,16]$. Mára már a klasszikusnak számító felületeket (esztergált, elektropolírozott, savazott, homokfúvott, anódikus oxidáció) részben felváltották a kombinált felület-kialakítási módszerek - mikor is az előbb említett eljárásokat egymás után alkalmazzák a gyártók -, kihasználva az egyes kezelések előnyeit [8]. A felületkezelés egyik speciális formája az anyagtranszport nélküli lézeres felületkezelés. Az irodalomban kevés adatot találunk ennek a módszernek az alkalmazásáról és eredményeiről [2, 8, 10, 11, 15].

Ennek figyelembe vételével tűztük ki célul az Arc-, Állcsont-, Szájsebészeti és Fogászati Klinikán beültetett lézeresen felületkezelt implantátumok 8-17 éves követéses vizsgálatát.

A lézeres felületkezelésnek két fajtája ismeretes:
1. impulzuslézerek, 2. excimerlézerek által kialakított felületek. Az excimerlézerek a nem termikus lézerek csoportjába tartoznak. Alkalmazásuk nem hőhatáson alapul, hanem mechanikai behatásokat okoznak [3]. Kutatócsoportunk impulzuslézerrel alakította ki a felszín sajátos struktúráját.

Az implantátum lézeres felületkezelését egy számítógép által vezérelt speciális készülék végezte. Az általunk vizsgált - és az MTA Múszaki Fizikai és Anyagtudományi Kutatóintézet Vékonyréteg és Nanoszerkezetek Osztályán kidolgozott és alkalmazott - lézeres felületkezelések esetében neodímium-üveg lézert alkalmaztunk.

A kezelések vákuumban, vagy célszerüen választott gázatmoszférában történtek. A felület legkülső rétegének hőmérséklete mégis viszonylag alacsonyabb a nagymértékú elpárolgás miatt, ezért a felszín alatti magasabb hőmérsékletü anyag mintegy „lerobbantja” a külső réteget. Az oldott gáztartalom buborékok formájában, krátereket hagyva maga után, elhagyja a felszínt. A besugárzás végeztével az olvadt anyagréteg, az implantátum érintetlen, hideg hatására néhány nanoszekundum alatt ismét megszilárdul és morfológiájában megőrzi az olvadt állapot utolsó pillanatában jelenlévő felületi alakzatokat, amelyek mérete 10-60 mikrométeres tartományba esik. A szilárd állapotban is folytatódó szupergyors lehúlés hatására dendrites kristályformák jelennek meg az 1-10 mikronos mérettartományban, tovább fokozva 


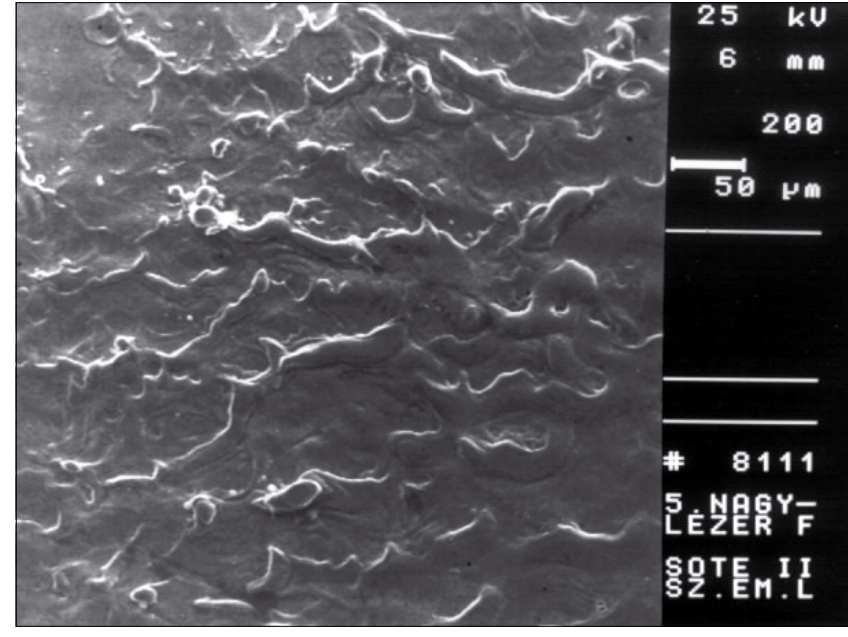

1. ábra: Nagy teljesítményű lézerrel kezelt felszínprofil SEM képe 200-szoros nagyításban, ahol jól ábrázolódik a felület elsődleges struktúrájának 50-60 mikrométeres mérete

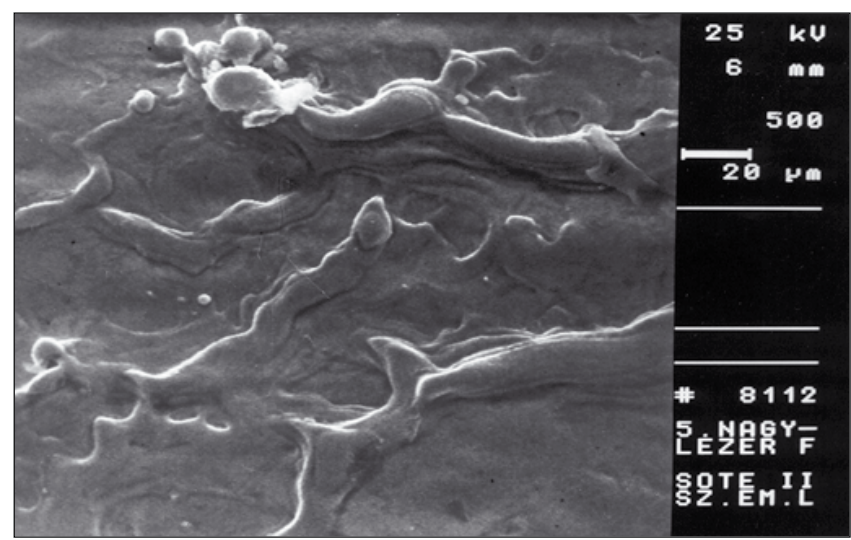

2. ábra: Nagy teljesítményű lézerrel kezelt felszínprofil SEM képe 500-szoros nagyításban, jól látszik a felszín 10-15 mikrométeres másodlagos struktúrája

a morfológia sokszínűségét. A lézerrel kezelt felület jellegzetes morfológiát mutat; szabályosan elhelyezkedő, hullámzásszerű elsődleges struktúra figyelhető meg egymástól 30-60 mikron távolságban pásztázó elektronmikroszkóp alatt. Ugyanakkor láthatóvá válik az úgynevezett körte formájú másodlagos struktúra is, amelynek nagysága 10-15 mikrométer és a felszíni dendritek, melyek a mikrométer vagy nanométeres nagyságrendü harmadlagos struktúrát alkotják. [2, 8, 10, 11, 15]. (1. és 2. ábra)

Az előbb leírt eljárás - melyet a klinikumban az Uniplant SP implantátumok esetében alkalmaztunk - az MTA Müszaki Fizikai és Anyagtudományi Kutatóintézet Vékonyréteg és Nanoszerkezetek Osztálya szabadalmaztatta [18]. Az implantátumokat a hódmezővásárhelyi Protetim Orvosi Müszergyártó Kft. gyártotta és a budapesti Sanitaria Kft. forgalmazta. Az Uniplant SP implantátumok felületkezelése során a lézersugár teljesítménye $3 \mathrm{~J} /$ impulzus volt.
Vizsgáltuk a fent említett módon történt felületkezelés után a 1997. január 1. és 2006. december 31. között beültetett implantátumok sikerességi és túlélési rátáját, valamint azt, hogy közép- és hosszútávon követett implantátumok milyen klinikai és radiológiai paraméterekkel rendelkeznek. Ezen adatok birtokában következtethetünk a lézeres felületkezelés eredményére, és összehasonlíthatjuk az értékekeket más szerzők jól dokumentált felületi morfológiai adataival [2, 4, 6].

\section{Anyag és módszer}

A beültetett implantátumok felületkezelése nagyteljesítményű $\mathrm{Nd} /$ üveg lézerrel történt (Uniplant $\mathrm{SP}$ ). Az implantátumokat két sebész helyezte be (D. T. és J. F. Á.) - akik szerzők is - a Semmelweis Egyetem Arc-, Állcsont-, Szájsebészeti és Fogászati Klinikán elfogadott és alkalmazott sebészi technikával. Az implantátumokat minden esetben a csont szintjébe helyeztük be, és korrekt protetikai pozícíóban, jó primér stabilitással rendelkeztek. A páciensekkel levél útján felvettük a kapcsolatot és felkértük őket a klinikai kutatásban történő részvételükre. A Helsinki Deklarációnak megfelelően minden beteget írásban tájékoztattunk a vizsgálat céljáról.

Kérdőív alapján vizsgáltuk a betegek általános egészségi állapotát, különös tekintettel gyógyszerszedési és dohányzási szokásaikra és ez eltelt években felmerülő - biológiai és technológiai - problémáikra, amelyek összefüggésben lehettek a beültetett implantátumukkal.

Az esetekről fotódokumentációt készítettünk. A radiológiai vizsgálatoknál a panorámaröntgen-felvételek mellett minden implantátumról intraorális (long-cone) felvételt is készítettünk.

A következő klinikai és radiológiai paramétereket mértük: 1. Vizsgáltuk a periimplantitis jelenlétét vagy hiányát

2. Plakk jelenlétét vagy hiányát

3. Ínyvérzés jelenlétét vagy hiányát

4. A szondázási mélységet (Probing Depth, PD): parodontális szondával, hat helyen az implantátum körül

5. Az implantátum válla és a marginális mucosa közötti távolságot (Distance from the Implant shoulder to the mucosal Margin, DIM value), parodontális szondával, hat helyen az implantátum körül [6]

6. Az implantátum válla és az első csontimplantátum kontaktpont közötti távolságot (Distance from the implant shoulder to the first Bone-to Implant contact, DIB-value), párhuzamos, long-cone technikával készült kisfelvételen, mesialis és distalis oldalon [6]

Mértük a sikerességi és túlélési rátát, elemeztük a vizsgálatban részt vevő páciensek általános egészségi állapotát. Rögzítettük a vizsgálatban résztvevők átlagéletkorát és a férfi/nő arányt.

Továbbá vizsgáltuk a protetikai indikációt (egy fog hiány, sorvégi hiány, hosszú sorközi hiány, teljes fog- 
hiány), amiért az implantátumot beültettük. Elemeztük a behelyezett implantátumok hosszát, átmérőjét.

Fontos kérdés volt a beültetett implantátumok lokalizációja (melyik régióba ültettük be). Vizsgáltuk továbbá, hogy az implantátum beültetése hány százalékban lett kiegészítve GBR technikával és annak melyik típusával.

$A z$ implantátumok klinikai és radiológiai eredményeit a Buser és mtsai által javasoltak alapján értékeltük [6].

$A z$ adatokat ROP stat 2,0 statisztikai programmal értékeltük.

\section{Eredmények}

A visszahívott páciensek közül 32 jelent meg a vizsgálaton: 14 nő $(43,7 \%)$ és 18 férfi $(56,3 \%)$ páciens. Átlagos életkoruk az implantáció időpontjában 52,8 év volt. Azoknál a pácienseknél, akik különböző időpontokban több implantátumot kaptak, az első mútét időpontját vettük figyelembe. A legtöbb beteg 50 év feletti volt és csak $20 \%$-uk volt 30 év alatti (Táblázat 1.). Általános egészségi állapotukat tekintve elmondhatjuk, hogy a 32 páciensből 5 dohányzott, 27 nem. 7 páciensnél hipertónia, háromnál cukorbetegség fordult elő, biszfoszfonát terápiában egyikük sem részesült. $A$ vizsgált csoportból 21-en használnak manuális fogkefét,

1. táblázat

A vizsgált betegek életkora a beültetéskor

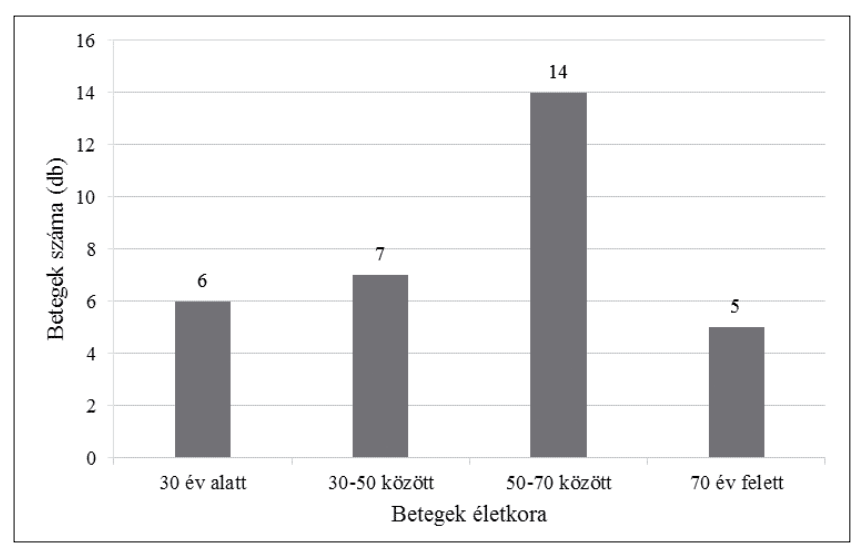

2. táblázat

A protetikai indikációk megoszlása

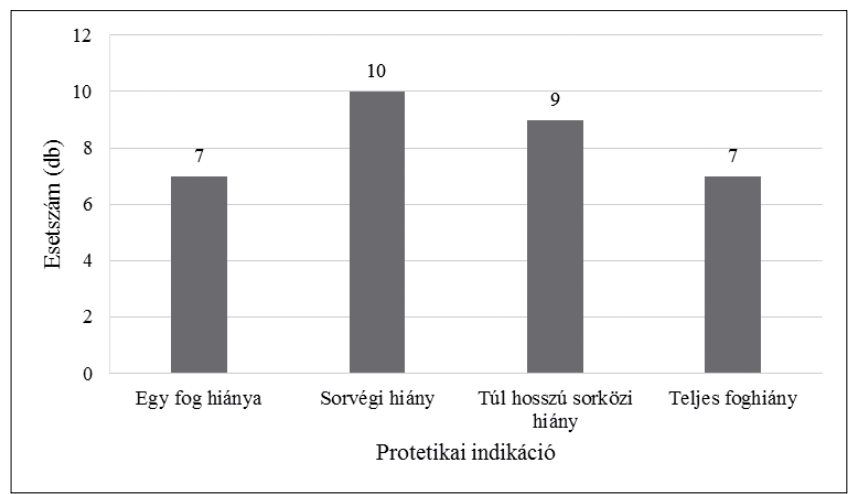

3. táblázat

Felső állcsontba beültetett implantátumok száma és elhelyezkedésük

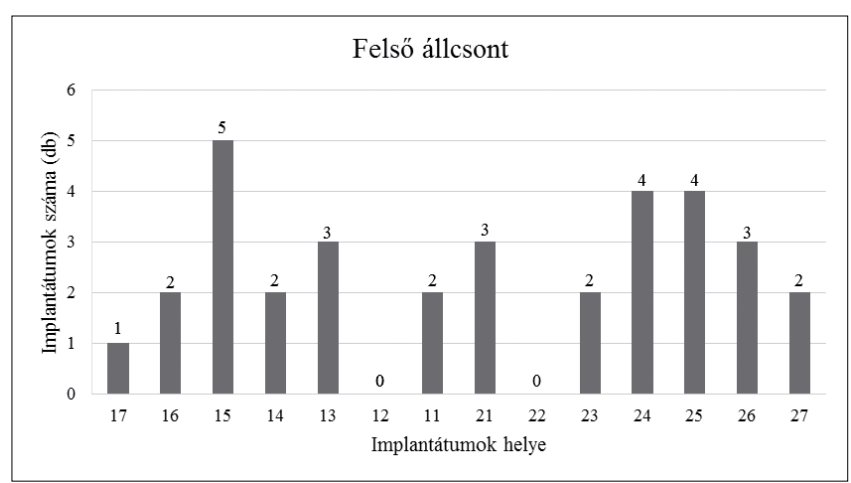

4. táblázat

Alsó állcsontba beültetett implantátumok száma és elhelyezkedésük

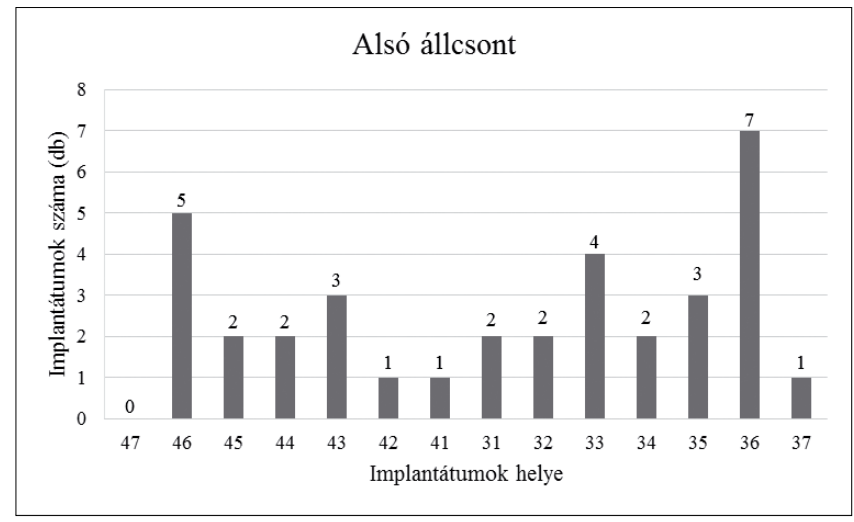

10-en elektromosat és 1 egyáltalán nem mossa a fogát, 9 használ rendszeresen fogköztisztító kefét.

A beültetett 68 implantátumnak a protetikai indikációs területe megfelelt a Magyarországon korábban mért adatoknak, azaz leggyakrabban sorvégi hiány miatt történt beültetés [12]. (Táblázat 2.)

Az összes implantátum közül a $10 \mathrm{~mm}$ hosszúságút alkalmaztuk a leggyakrabban [32\%], majd a 12 mm-es következett. Az implantátumok több mint fele $(61,7 \%)$ 3,5 vagy $4,0 \mathrm{~mm}$ átmérőjü volt.

A beültetett implantátumok lokalizáció szerinti elosztása szintén megegyezik a korábban mért magyarországi gyakorlattal, azaz a legtöbb implantátum az alsó állcsont első molárisának (17,6\%) hiányát pótolta. A felső állcsont esetében a premolárisok pótlására volt a legnagyobb szükség [10]. (Táblázat 3., 4.)

Az esetek 84,4\%-ában nem volt szükség csontpótlásra. 15,6\%-ban alkalmaztunk GBR technikát és minden esetben sinus-liftet végeztünk, az implantációt megelőzően 6-8 hónappal. Ezek az arányok megfelelnek a nemzetközi és a hazai irodalomban leírtaknak $[12,17]$. 


\section{Sikerességi és túlélési ráta}

A 8-17 évvel ezelőtt beültetett és általunk most vizsgált implantátumok (68 darab) közül kettő volt „sikertelen" periimplantitis és kóros mozgathatóság miatt. Mindkettőt eltávolítottuk a vizsgálat után (3. ábra). Implantátumtörésünk nem volt. A Buser és mtsai által leírt

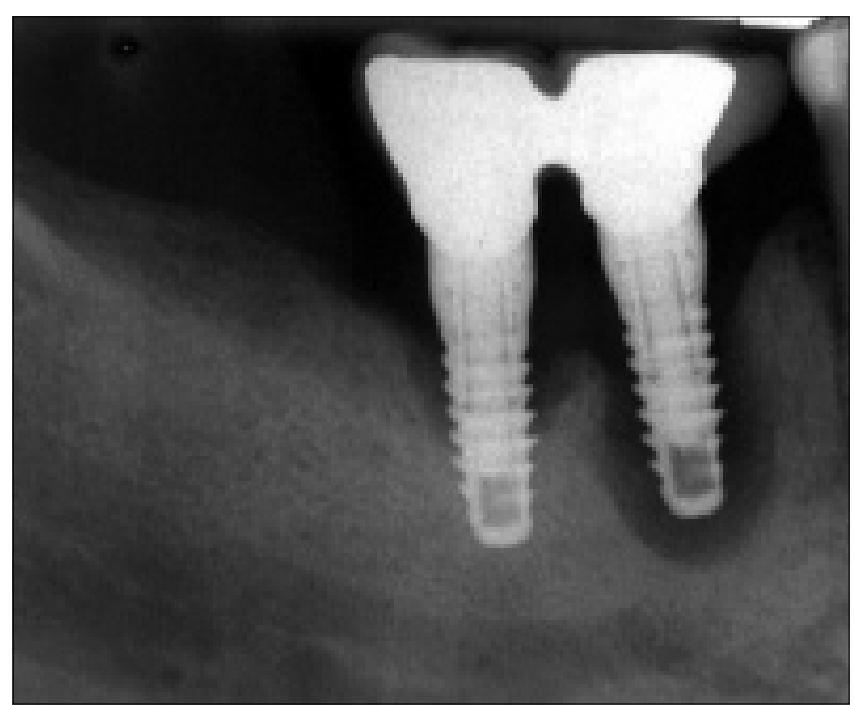

3. ábra: A két sikertelen implantátum radiológiai képe

klasszifikáció alapján sikertelenségünk 2,94\% volt [5]. (Táblázat 5.) Ugyanakkor 3 esetben volt „túlélő” implantátumunk, ahol vagy progresszív csontpusztulást, vagy pus jelenlétét tapasztaltuk kóros mozgathatóság nélkül. A „uúlélő" implantátumok aránya $4,41 \%$ volt.

Ennek a klasszifikációnak az értelmében a vizsgálatunkban részt vevő implantátumok sikerességi rátája 92, 64\%, míg a túlélési rátája 97, 05\% volt. (Táblázat 6.)

A lézeresen felületkezelt és a homokfúvott-savazott felszíni csoportok összehasonlítása azt jelzi, hogy bár az elemszámok között nagyságrendi különbség van, ez a statisztikai próbát nem érinti. A két vizsgálat során a sikerességben statisztikailag nem mutatható ki különbség, vagyis a két felszín között a sikeresség szempontjából nem lehet különbséget tenni. (Táblázat 7.)
5. táblázat

A sikeresség és a sikertelenség klasszifikációja (Buser és mtsai szerint)

\begin{tabular}{|l|c|}
\hline Klinikai státusz & Klasszifikáció \\
\hline $\begin{array}{l}\text { Eltávolított, elvesztett, mozgó } \\
\text { vagy eltört implantátum }\end{array}$ & sikertelen \\
\hline $\begin{array}{l}\text { Régebben előforduló akut gyulladásban lévő } \\
\text { implantátum } \\
\text { pus/progresszív csontpusztulás jelenlétével }\end{array}$ & túlélő \\
\hline $\begin{array}{l}\text { Akut gyulladásban lévő implantátum } \\
\text { pus/progresszív csontpusztulás jelenlétével }\end{array}$ & túlélő \\
\hline Implantátum kielégíti a sikeresség kritériumát & sikeres \\
\hline
\end{tabular}

6. táblázat

A vizsgált, lézerrel felületkezelt implantátumok sikerességi és túlélési rátája

\begin{tabular}{|l|c|c|}
\hline Kritérium & $\mathbf{n}$ & $\%$ \\
\hline Sikertelen implantátum & 2 & 2,94 \\
\hline „Túlélő” implantátum & 3 & 4,41 \\
\hline Sikeres implantátum & 63 & 92,64 \\
\hline Összes implantátum & 68 & 100 \\
\hline Sikerességi ráta & & 92,64 \\
\hline Túlélési ráta & & 97,05 \\
\hline
\end{tabular}

\section{Klinikai vizsgálatok eredményei}

A 68 implantátum közül 5 esetben tapasztaltuk a periimplantitis valamilyen formájú megjelenését. Ezek közül 3 esetben suppuratiót, pus jelenlétét is észleltük. Fistulával egy esetben sem találkoztunk.

Az esetek 64,71\%-ban plakkmentességet tapasztaltunk és a parodontális szonda használatakor $48,53 \%$ ban tapasztaltunk vérzést a sulcusból.

Probing Depth (PD) próbával, parodontális szondával hat helyen mértük a szondázási mélységet az implantátum körül. A legkisebb szondázási mélység $0 \mathrm{~mm}$, míg a legnagyobb $12 \mathrm{~mm}$ volt. Az átlagos PD érték (mPD) $3,33 \mathrm{~mm}$ volt (szórás: $\pm 1,66$ ).

A két felszín sikerességének statisztikai összefoglaló táblázata

\begin{tabular}{|c|c|c|c|c|c|c|c|c|c|c|c|c|}
\hline $\begin{array}{l}\text { Változó } \\
\text { érték }\end{array}$ & $\begin{array}{l}\text { Lézeres } \\
\text { felszín }\end{array}$ & Szórás 1 & $\begin{array}{c}\text { Homokfúvott } \\
\text { /savazott }\end{array}$ & Szórás 2 & $\begin{array}{l}\text { Hatás } \\
\text { Cohen-d }\end{array}$ & $\begin{array}{l}\text { Varbom } \\
\text { p/Levene }\end{array}$ & t-érték & f & p-érték & Welch-d & f & p- \\
\hline Sikeresség & 1,971 & 0,168 & 1,988 & 0,108 & -144 & 101 & $-1,132$ & 579 & 0,258 & $-0,818$ & 770 & 0,417 \\
\hline
\end{tabular}

Welch-féle próba csoportonkénti alapstatisztikája

\begin{tabular}{|c|l|c|c|c|c|c|c|c|}
\hline Index & Study & Esetszám & Átlag & Szórás & Min & Max & Ferdeség & Csúcsosság \\
\hline 1 & Lézeres felszín & 68 & 3,319 & 1,653 & 1 & 7,833 & $1,328^{\star * *}$ & $2,871^{\star * *}$ \\
\hline 2 & Homokfúvott/savazott & 503 & 3,278 & 1,065 & 1 & 8 & $0,829^{\star * *}$ & $1,519^{\star * *}$ \\
\hline
\end{tabular}


Elvégezve a normalitásvizsgálatot, azt az eredményt kaptuk, hogy a lézeres felszínnel kapcsolatos vizsgálatoknál az adatok eloszlása nem felelt meg a normálnak, míg Buser és mtsai esetében igen. Ez azt jelenti, hogy a vizsgálatnál a Welch-féle d-próbát kell alkalmazni. A Welch-féle próba azt mutatta, hogy a két minta szignifikánsan nem tér el. (Táblázat 8.)

Mértük az implantátum válla és marginális mucosa közötti távolságot (DIM value) hat helyen az implantátum körül. A minimális érték -6, míg a maximális érték 0 volt. Az mDIM értékre -0,72-őt kaptunk (szórás: $\pm 1,25$ ), vagyis az íny visszahúzódása átlagosan $0,72 \mathrm{~mm}$ volt.

Itt egyik esetben sem sérült a normalitás, így a következőkben kétmintás t-próbát alkalmaztunk. 95\%-os konfidencia-intervallum a két elméleti átlag $\mathrm{m} 1-\mathrm{m} 2$ különbségére, a kétmintás t-próba alapján: $C(0,95)=$ $(0,580,0,062)$, a Welch-féle d-próba alapján: $C(0,95)=$ $(-0,533,0,015)$. Így itt sincs statisztikailag szignifikáns különbség a két minta között.

\section{Radiológiai vizsgálat eredménye}

Long-cone technikával minden implantátumról felvételt készítettünk és ezeken mértük az implantátum válla és az első csontimplantátum kontaktpont közötti távolságot mesialis és distalis oldalon (DIB-value). A méréseket az „ImageJ” számítógépes programmal végeztük - melyet a National Institutes of Health direkt ilyen célra fejlesztett ki-, majd a mérési eredményeket kiértékeltük. DIB minimális értéke 1,36, maximális értéke 12,11 volt, míg az átlaga 3,66 (szórás: $\pm 1,5$ ). Itt a normalitás nem teljesül mindkét vizsgálat esetében, így a Welchféle d-próbát kellett ismét használni.

\section{Megbeszélés}

Retrospektív vizsgálatunkban a közép- és hosszútávú eredményeket összegeztük a nagyteljesítményű Nd-üveg impulzus lézersugárral kezelt implantátumok esetében. Tekintettel arra, hogy az irodalomban lézerrel felületkezelt implantátumokról klinikai kiértékelést nem találtunk, különösen érdekes lehet ez a vizsgálat. Az általunk alkalmazott lézerrel kezelt felület legfőbb jellemzője a nagy felületi tisztaság (az alkalmazott vákuum, illetve az eredeti felületi réteg elpárolgása miatt) és a speciális felületi morfológia. A felület zárt üregektôl és zárványoktól mentes, túlélő bakteriális gócokat nem tartalmaz.

Éppen azért, mert a legtöbb felületkezelési eljárás legnagyobb problémája a felületi szennyeződés elkerülése, érdemes nagyobb hangsúlyt és figyelmet fordítani a jövőben a lézeres felületkezelésre. A hazánkban a lézeresen felületkezelt implantátumok hosszútávú sikerességi eredményeivel eddig nem rendelkeztünk. Az előzetes állatkísérletes és egyéb vizsgálataink kecsegtető eredményeket mutattak [10,11, 15]. Ismertebb nemzetközi implantációs rendszerek közül a SIS ${ }^{\circledR} \mathrm{im}$ plantátum rendelkezik lézeres felülettel [9].

A lézeres felületkezelésről az irodalomban csekély számú adatot lehet fellelni. Gaggl és mtsain és a mi kutatócsoportunkén kívül még a szegedi és a debreceni egyetem munkacsoportja foglalkozott lézeresen felületkezelt felszínek morfológiájával [3, 8, 9, 14].

A kapott eredményeket akkor tudjuk értékelni, ha összehasonlítjuk más, jól dokumentált felületi morfológia értékeivel. Az irodalomban jelenleg a homokfúvott és kémiai maratáson átesett „kombinált” felületekről van a legtöbb információnk. Az általunk mért értékeket is ehhez a felszínhez (mint referencia felszíni struktúra) hasonlítjuk. A Buser és mtsai által leírt 10 éves retrospektív vizsgálatban kapott értékeket vetjük össze a mi eredményeinkkel [6].

A vizsgálatunkban részt vevő implantátumok sikerességi rátája 92,647\%, ami elmarad az SLA felszín hez képes (97\%), míg a túlélési ráta 97,058\% volt, ami közelít az SLA felszín 98,0\%-os értékéhez. A sikerességi rátánál mért különbség adódhat abból, hogy a mi vizsgálatunkban sokkal kisebb az elemszám, mint a referencia esetében. (Táblázat 9.) Ugyanakkor a két vizsgálatot összehasonlítva a statisztikai elemzés után szignifikáns különbséget nem kaptunk. A szondázási mélység esetében kapott $3,33 \mathrm{~mm}$ átlagos $P D$ értékhez (szórás: $\pm 1,66$ ) képest Buser és mtsai $m P D=3,27$ kaptak. A DIM érték esetében a mi vizsgálatunkban $-0,72 \mathrm{~mm}$-t kaptunk, míg a referencia $-0,42 \mathrm{~mm}$-t mért. $A$ radiológiailag mért DIB érték esetében a lézerrel felületkezelt implantátumunk átlagosan 3,66 mm-t mutattak, míg az SLA felszín 3,32 mm-t.

Mindezen eredmények ismeretében - összehasonlítva egy alaposan dokumentált felszín értékeivel - megállapítható, hogy a nagyteljesítményú lézerrel felületkezelt implantátumok klinikailag közép- és hosszútávon is megbízható eredményeket mutatnak.

9. táblázat

A vizsgált lézerrel felületkezelt implantátumok klinikai és radiológiai paraméterei

\begin{tabular}{|l|c|c|l|c|}
\hline Paraméterek & Min & Max & Átlag & Szórás \\
\hline Probing Depth(PD) & 0 & 12 & 3,33 & 1,66 \\
\hline DIM & -6 & 0 & 0,721 & 1,25 \\
\hline DIB & 1,36 & 12,11 & 3,66 & 1,5 \\
\hline
\end{tabular}

Irodalom

1. Albrektsson T, Brånemark PI, Hansson HA, Lindström J: Osseointegrated titanium implants. Acta Orthop Scand 1981; 52: 155-170.

2. Allegrini $S$ Jr, Yoshimoto $M$, Salles MB, de Almeida Bressiani AH: Biologic response to titanium implants with laser-treated surfaces. Int J Oral Maxillofac Implants 2014; 29: 63-70.

3. Bereznai M, Pelsőczi l, Tóth Z, Turzó K, Radnai M, Bor Z, FazeKAS A: Surface modifications induced by ns and sub-ps excimer laser pulses on titanium implant material. Biomaterials 2003; 24: 4197-4203. 
4. Buser D1, Janner SF, Wittneben JG, Brägger U, Ramseier CA, SALVI GE: 10-year survival and success rates of 511 titanium implants with a sandblasted and acid-etched surface: a retrospective study in 303 partially edentulous patients. Clin Implant Dent Relat Res. 2012; 14: 839-845.

5. Buser D, Broggini N, Wieland M, Schenk RK, Denzer AJ, Cochran DL, Hoffmann B, Lussi A, Steinemann SG: Enhanced bone apposition to a chemically modified SLA titanium surface. $J$ Dent Res 2004; 7: 529-533.

6. Buser D, Janner SeM, Wittneben JG, Bragger U, Ramseier ChA, SALVI GE: 10-year survival and succes rates of 511 titanium implants with sandblasted and acid-etched surface: a retrospective study in 303 partially edentulous patients. Clin Implant Dentistry Related Res 2012; 14: 839-851.

7. Buser D, Weber HP, LANG NP: Tissue integration of non-submerged implants. 1-year results of a prospective study with 100 ITI hollow-cylinder and hollow-srew implants. Clin Oral Implants Res 1990; 1: 33-40.

8. Gaggl A, Schulter G, Müller WD, Karchen M: Scanning electron microscopical analysis of laser treated titanium implant surfaces - a comparative study. Biomaterials 2000; 21: 1067-1073.

9. GagGl A, Schultes G, Müller WD, Rainer H: Licht- und elektronmikroskopische analyse laserbearbeiteter Titanimplantate. Implantologie 2000; 1: 21-31.

10. Joóв FÁ: Fogászati implantátumok felületi morfológiájának vizsgálata. PhD Thesis, Budapest, 2004.
11. Joób FÁ, Divinyı T, Fazekas Á, Daróczı Cs, Karacs A, Pető G: Pulsed laser induced micro and nanosized morphology and composition of titanium dental implants. Smart Materials and Structures 2002; 11: 819-824.

12. Joób FÁ, Kerekes F, Koppány F, Pfeifer B, Divinyı T: Az implantációs sebészeti beavatkozások indikációs területeinek változása a statisztikai vizsgálatok tükrében. Fogorv Szle 2007; 100: 103-107.

13. Orsini G, Assenza B, Scarano A, Piatteli M, Piatteli A: Surface analysis of machined versus sandblasted and acid-etched titanium implants. Int J Oral Maxillofac Implants 2000; 15: 779-784.

14. Pelsőczi KI, Bereznal M, Tóth Zs, Turzó K, Radnal M, Bor Zs, FAZEKAS A: Titán minták felületének módosítása excimer lézerrel a hatékonyabb osszeointegráció érdekében. Fogorv Szle 2004; 97: 231-237.

15. Pető G, Karacs A, PÁsztı Z, Guczı L, Divinyı T, Joób FÁ: Surface treatment of screw shaped titanium dental implants by high intensity laser pulses. Appl Surface Science 2002; 186: 7-13.

16. Schwarz F, Herten M, Sager M, Wieland M, Dard M, Becker J: Bone regeneration in dehistenc-type defects at chemically modified (SLActive) and convencional SLA titanium implants: a pilot study in dogs. J Clin Periodontol 2007; 34: 78-86.

17. Sulzer TH, Bornstein MM, Buser, D: Aktuelles Indikationspektrum in der oralen Implantologie an einer Überweisungsklinik. Schweiz Monatsschr Zahnmed 2004; 114: 444-450.

18. Magyar Szabadalom P217111/119; 1997

\section{Joób F Á, Divinyı T, Karacs A, Koncz Sz, Pető G, Sulyok L}

\section{Survival and success rate of dental implants treated with high intensity laser}

Clinical and radiological evaluations have been performed in patients with high energy $\mathrm{Nd}$ : glass laser treated dental implants with. These patients underwent dental implantation surgery between 1997 and 2006 . Strict success criteria were used for the examination and analysis of implants.

Based on clinical and radiological evaluation, success and survival rates of laser surface treated dental implants were similar to those of sandblasted, acid-etched surface implants frequently reported in the literature. Specific surface morphology and high degree of purity of laser surface treated dental implants ensure excellent osseointegration and a good clinical performance also on the long term.

Keywords: dental implant, success rate, surface morphology, survival rate, laser treated surface, clinical and radiological evaluation 